\title{
Combined Effects of Nutrient Management on Nutrient Content and Uptake of Transplant Aus Rice (BRRI Dhan48)
}

\author{
Nahid Kaisar ${ }^{1}$, Abu Zofar Md. Moslehuddin², Md. Mahbubul Alam Tarafder ${ }^{3} \&$ Md. Sohanur Rahman ${ }^{4}$ \\ ${ }^{1}$ Department of Soil Science, Bangladesh Agricultural University, Bangladesh \\ ${ }^{2}$ Professor, Department of Soil Science, Bangladesh Agricultural University, Bangladesh \\ ${ }^{3}$ Senior Scientific Officer, Soil Science Division, Bangladesh Institute of Nuclear Agriculture, Bangladesh \\ ${ }^{4}$ Scientific Officer, Department of Entomology, Bangladesh Jute Research Institute, Bangladesh \\ Correspondence: Md. Sohanur Rahman, Scientific Officer, Department of Entomology, Bangladesh Jute Research \\ Institute, Bangladesh. E-mail: sohanbau2010@gmail.com
}

Received: May 21, 2020 Accepted: June 7, 2020 Online Published: June 12, 2020

\begin{abstract}
A field experiment was conducted at Sutiakhali, Mymensingh for crop production and chemical analysis was performed at Department of soil science, Bangladesh Agricultural University, Mymensingh to see the combined effect of nutrient management on nutrient content and uptake of Transplant Aus rice (BRRI dhan48) during march to july 2015 following Randomized Complete Block Design with four replications. The treatments were T1: RD (N75 P12 K45 S9), T2: STB (N74 P11 K36 S7), T3: INM (N54 P5 K27 S5+ CD @ 5.0 t ha-1), T4: Farmer's practice (N69 P30 K37), and T5: Control (no fertilizer). The NPKS content and uptake by BRRI dhan48 were also influenced significantly due to combined use of manure and fertilizers. The maximum N, P, K and $\mathrm{S}$ uptake by grain $(35.55,6.99,15.20$ and $3.38 \mathrm{~kg} /$ ha respectively) were obtained from the application of Integrated Nutrient Management. The minimum N, P, K and S uptake by grain (20.08, 3.64, 8.35 and $1.74 \mathrm{~kg} / \mathrm{ha}$ respectively) were found from T5: Control. Similarly, The maximum N, P, K and S uptake by straw (3.38, 5.43, 99.25 and 7.37 $\mathrm{kg} /$ ha respectively) were found from T3: INM. The minimum N, P, K and S uptake by straw $(1.74,2.67,49.70$ and $3.87 \mathrm{~kg} /$ ha respectively) were obtained from T5 (Control). The performance of the treatment T3 was better than T1, T2, T4 and T5 in nutrient content and uptake of BRRI dhan48. Considering nutrient content and uptake, the application of chemical fertilizers in combination with manure based on INM could be recommended for BRRI dhan48 production in aus season.
\end{abstract}

Keywords: nitrogen, phosphorous, potassium, sulphur, grain, straw, fertilizer, BRRI dhan48, soil

\section{Introduction}

Rice is the staple food crop in Bangladesh. Plant nutrients are essential for proper crop development, plant growth and also of their internal metabolism. Soil with low organic matter, inappropriate use of chemical fertilizers, low use of organic manures made the situation difficult (Karim et al. 1994). Uneven use of fertilizers has a adverse effect on crop production (Rijpma and Jahiruddin, 2004). Crop production is not totally maintained only chemical fertilizers and not possible to obtain higher crop yield by using organic manures alone (Bair, 1990). Nambiar (1991) reviewed that, combined use of organic manure and chemical fertilizers would be important in providing greater stability in production and maintaining soil fertility status.

Combined Nutrient Management (CNM) is a technique where organic, inorganic, and biofertilizer can be combindly applied to soils for crop growth and get good yield. The object of INM is to optimize crop nutrition, the functioning of the soil health, and minimize nutrient losses or avoiding adverse effect on the environment. Application of manures and different doses of chemical fertilizers significantly increased the yield components and grain and straw yields of BINA dhan7 (Malika et al. 2011). Combined nutrient application leads to higher yield. (Lin et al. 2009 and Qian et al.2011). Application of manures and different doses of urea-N fertilizers significantly increased the yield contributing attributes of BRRI dhan29 (Rahman et al. 2009).

A proper combination of nutrients is important for sustainable agriculture for providing food with good quality. Cowdung, poultry manure and compost supply the macro and micronutrients for crop production. Cowdung is a good source of nutrients that can be mixed into most fertilizer schedules. Considering value, manure is most important sources. Manure application in association with recommended fertilizer dose plays important role in rice 
production. Therefore, the present research work was undertaken to know the nutrient content and uptake of Transplant Aus rice (BRRI dhan48) in combined nutrient management.

\section{Materials and Methods}

\subsection{Site and Weather Description}

The field experiment was done at Sutiakhali, a village of Mymensingh Sadar upazila and laboratory analysis was done at The Department of soil science, Bangladesh Agricultural University District during january-july 2015.The experimental site is situated at latitude N: $24^{\circ} 40.982^{\prime}$ and longitude E: $90^{\circ} 27.391^{\prime} 24^{\circ} \mathrm{N}$ at a height of $8.3 \mathrm{~m}$ above the mean sea level under Old Brahmaputra Floodplain Agro-ecological zone. Physical characteristics of soil were sand $27.06 \%$, silt $63.40 \%$ and clay $9.54 \%$. Textural class was silt loam. Drainage system was moderate. Chemical characteristics of soil were $\mathrm{pH}(6.53)$, organic matter $(1.35 \%)$, total $\mathrm{N}(0.10 \%)$, available $\mathrm{P}\left(6.0 \mathrm{mg} \mathrm{\textrm {kg } ^ { - 1 }}\right)$, Exchangeable K $\left(0.097 \mathrm{cmol}^{+} \mathrm{kg}^{-1}\right)$, available $\mathrm{S}\left(9.3 \mathrm{mg} \mathrm{kg}{ }^{-1}\right)$ and available $\mathrm{Zn}\left(0.41 \mathrm{mg} \mathrm{kg}^{-1}\right)$. The weather information ranged temperature (max. $23.9^{\circ} \mathrm{c}-35.4^{0} \mathrm{c} \& \min .11 .3^{0} \mathrm{c}-26.7^{0} \mathrm{c}$ ) rainfall (Nil $-? ? 299.9 \mathrm{~mm}$ ) and humidity (76-86.6\%) prevailed at the experimental site during the cropping season of conducting the experiment (Source: Department of Irrigation and Water Management, Bangladesh Agricultural University, Mymensingh). 0-15 cm depth soil collected for samples. The samples were then stored in clean plastic bags for subsequent chemical and mechanical analysis. The planting material used for the experiment was transplanted aus rice. The variety was BRRI dhan 48 .

\subsection{Experimental Design and Treatments}

The experiment was done by Randomized Complete Block Design (RCBD) where the experimental area was divided into 4 blocks and each block was subdivided into 5 plots. Treatments distributed randomly to the unit plots in each block. Total unit plot was 20 and plot size was $4.5 \mathrm{~m} \mathrm{x} 3.15 \mathrm{~m}$ and the spacing among the plots was $20 \mathrm{~cm}$. There were five treatments as follows: $\mathrm{T}_{1}$ : RD (Recommended Dose $\left(\mathrm{N}_{75} \mathrm{P}_{12} \mathrm{~K}_{45} \mathrm{~S}_{9}\right)$ ), $\mathrm{T}_{2}$ : STB (Soil Test Basis $\left(\mathrm{N}_{74} \mathrm{P}_{11}\right.$ $\mathrm{K}_{36} \mathrm{~S}_{7}$ )), $\mathrm{T}_{3}: \mathrm{N}_{54} \mathrm{P}_{5} \mathrm{~K}_{27} \mathrm{~S}_{5}$ (Combined Nutrient Management (CNM) + CD ( Cowdung) @ $5.0 \mathrm{t} \mathrm{ha}^{-1}, \mathrm{~T}_{4}$ : Farmer's practice (N69 P30 K37) and T5: Control (no fertilizer).

\subsection{Name, Rates and Sources of Nutrients Application}

Table 1. Name, rates and sources of nutrients applied as follows

\begin{tabular}{lllll}
\hline $\begin{array}{c}\text { Name of } \\
\text { fertilizer }\end{array}$ & Treatments & $\begin{array}{l}\text { Nutrient } \\
\text { rate }(\mathrm{kg} / \mathrm{ha})\end{array}$ & $\begin{array}{l}\text { Fertilizer rate } \\
(\mathrm{kg} / \mathrm{ha})\end{array}$ & $\begin{array}{l}\text { Fertilizer rate } \\
(\mathrm{g} / \mathrm{plot})\end{array}$ \\
\hline \multirow{4}{*}{ Urea } & $\mathrm{T}_{1}$ & 75 & 163.04 & 232 \\
& $\mathrm{~T}_{2}$ & 74 & 160.51 & 228 \\
& $\mathrm{~T}_{3}$ & 54 & 117.03 & 166 \\
& $\mathrm{~T}_{4}$ & 69 & 149.81 & 213 \\
\hline \multirow{4}{*}{$\mathrm{TSP}$} & $\mathrm{T}_{1}$ & 12 & 60.00 & 85 \\
& $\mathrm{~T}_{2}$ & 11 & 56.25 & 80 \\
& $\mathrm{~T}_{3}$ & 5 & 26.25 & 37 \\
& $\mathrm{~T}_{4}$ & 30 & 149.81 & 213 \\
\hline \multirow{3}{*}{ MoP } & $\mathrm{T}_{1}$ & 45 & 90.00 & 128 \\
& $\mathrm{~T}_{2}$ & 36 & 71.87 & 102 \\
& $\mathrm{~T}_{3}$ & 27 & 53.47 & 76 \\
& $\mathrm{~T}_{4}$ & 37 & 74.90 & 106 \\
\hline \multirow{2}{*}{ Gypsum } & $\mathrm{T}_{1}$ & 9 & 50.00 & 71 \\
& $\mathrm{~T}_{2}$ & 7 & 40.74 & 58 \\
\hline CD & $\mathrm{T}_{3}$ & 5 & 26.30 & 37 \\
\hline
\end{tabular}

\subsection{Application of Manures and Fertilizers}

The amounts of nitrogen, phosphorus, potash and sulphur fertilizers required per plot were calculated as per the treatments. Cowdung was applied before one week of transplanting (9 April 2015). The full dose of TSP, MoP and Gypsum were applied one day before transplanting (15 April 2015). Nitrogen from urea was applied in 3 equal splits. The first split of urea was applied after 15 days of transplanting (1 May 2015). Second split was applied as 
top dressing after 30 days of transplanting (16 May 2015) and the third split of urea after 45 days of transplanting (31 May 2015) i.e. at panicle initiation stage.

\subsection{Harvesting and Data Recording}

The crop was harvested at full maturity on 20 july 2015 . The harvested crop from each plot was bundled separately and brought to the threshing floor and threshed plot-wise. Grain and straw yields were recorded plot-wise and expressed as $\mathrm{t}$ ha- 1 on the basis of $14 \%$ moisture content.

\subsection{Chemical Analyses of Plant Samples}

Preparation of plant samples

The representative grain and straw samples were dried in an oven at $65^{\circ} \mathrm{C}$ for about 24 hours before they were ground by a grinding machine and stored in paper bags and finally kept into a desiccator until analysis.

Digestion of plant samples for total nitrogen determination

An amount of $0.1 \mathrm{~g}$ of oven dry ground plant sample (both grain and straw separately) was taken in a micro-kjeldahl flask for nitrogen determination. $1.1 \mathrm{~g}$ catalyst mixture $\left(\mathrm{K}_{2} \mathrm{SO}_{4}: \mathrm{CuSO}_{4} .5 \mathrm{H}_{2} \mathrm{O}: \mathrm{Se}=100: 10: 1\right), 2 \mathrm{ml} 30 \% \mathrm{H}_{2} \mathrm{O}_{2}$ and $3 \mathrm{ml} \mathrm{H}_{2} \mathrm{SO}_{4}$ were added into the flask. It was swirled and allowed to stand for 30 minutes. Then heating was continued until the digest was clear and colorless. After cooling, the content was taken into a $100 \mathrm{ml}$ volumetric flask and the volume was made up to the mark with distilled water. A reagent blank was prepared in a similar manner. The digest was used for nitrogen determination.

\section{Digestion of plant samples for $P, K$ and $S$ determination}

Plant sample of $0.5 \mathrm{~g}$ (grain or straw) was transferred into dry clean $100 \mathrm{ml}$ Kjeldahl flask. $10 \mathrm{ml}$ of di-acid mixture $\left(\mathrm{HNO}_{3}: \mathrm{HClO}_{4}=2: 1\right)$ was added into the flask. After leaving for a while, the flasks were heated at a temperature of $200^{\circ} \mathrm{C}$. When the flask became sufficiently clear and colorless, it boiled. After cooling, the digests was transferred into a $100 \mathrm{ml}$ volumetric flask and the volume was made up to the mark with distilled water. This digest was used for the determination of $\mathrm{P}, \mathrm{K}$ and $\mathrm{S}$.

\subsection{Determination of N, $P, K$ and $S$ from Plant Samples}

\section{Nitrogen}

Nitrogen content digests were determined by micro-kjeldahl method. $40 \% \mathrm{NaOH}$ was added for distillation after digestion complete. The evolved ammonia was trapped into $4 \% \mathrm{H}_{3} \mathrm{BO}_{3}$ solution and 5 drops of mixed indicator of bromocressol green $\left(\mathrm{C}_{21} \mathrm{H}_{14} \mathrm{O}_{5} \mathrm{Br} 4 \mathrm{~S}\right)$ and methyl red $\left(\mathrm{C}_{10} \mathrm{H}_{10} \mathrm{~N}_{3} \mathrm{O}_{3}\right)$ solution. Finally the distillate was titrated with standard $0.01 \mathrm{~N} \mathrm{H}_{2} \mathrm{SO}_{4}$ until the color changed from green to pink.

\section{Phosphorus}

Phosphorus was determined following the procedure of using $1 \mathrm{ml}$ digest for grain sample and $2 \mathrm{ml}$ digest for straw sample from $100 \mathrm{ml}$ extract. Then the sample was shaking with $0.5 \mathrm{M} \mathrm{NaHCO}_{3}$ solution at $\mathrm{pH} 8.5$ following Olsen method. The extracted phosphorus was determined by developing blue color by $\mathrm{SnCl}_{2}$ reduction of phosphomolybdate complex and measuring the intensity of color spectrophotometrically at $660 \mathrm{~nm}$ wavelength. The readings were calibrated to the standard $\mathrm{P}$ curve.

\section{Potassium}

$5 \mathrm{ml}$ of digest for the grain and $10 \mathrm{ml}$ for the straw was taken with $1.0 \mathrm{~N} \mathrm{NH}_{4} \mathrm{OAc}(\mathrm{pH}$ 7) and diluted to $50 \mathrm{ml}$ volume to make desired concentration. $\mathrm{K}$ was determined from the extract by using Flame photometer and calibrated with a standard curve.

\section{Sulphur}

Sulphur was determined by using $10 \mathrm{ml}$ of digest (both for grain and straw) from $100 \mathrm{ml}$ extract with $\mathrm{CaCl}_{2}$ solution $(0.15 \%)$. The $\mathrm{S}$ content in the extract was estimated turbidimetrically and readings were taken by spectrophotometer at $420 \mathrm{~nm}$.

\subsection{Determination of Nutrient Uptake}

After chemical analysis of grain and straw samples, the nutrient content were calculated and from the value of nutrient concentration. Nutrient uptakes were also calculated by the following formula: 
Nutrient content $(\%)$ x Yield $(\mathrm{kg} / \mathrm{ha})$

Nutrient Uptake $=$

100

\section{Statistical analysis}

The analysis of variance for nutrient content of the plant samples were done following the ANOVA technique and the mean results in case of significant F-value were adjudged by the Duncan's Multiple Range Test (DMRT).

\section{Results}

\subsection{Nutrient Content in Rice Grain and Straw of BRRI dhan 48}

The results of N, P, K and S contents of grain and straw have discussed under the following sub-sections. All data were statistically significant.

Table 2. N, P, K and S content in grain and straw of BRRI dhan 48 as influenced by combined nutrient management

\begin{tabular}{lllllllll}
\hline \multirow{2}{*}{ Treatment } & $\mathrm{N}(\%)$ & & $\mathrm{P}(\%)$ & \multicolumn{3}{c}{$\mathrm{K}(\%)$} \\
\cline { 2 - 8 } & Grain & Straw & Grain & Straw & Grain & Straw & Grain & Straw \\
$\mathrm{T}_{1}$ & $0.734 \mathrm{a}$ & $0.441 \mathrm{c}$ & $0.138 \mathrm{ab}$ & $0.073 \mathrm{~b}$ & $0.293 \mathrm{~b}$ & $1.423 \mathrm{~b}$ & $0.067 \mathrm{a}$ & $0.113 \mathrm{a}$ \\
$\mathrm{T}_{2}$ & $0.698 \mathrm{~b}$ & $0.469 \mathrm{~b}$ & $0.141 \mathrm{a}$ & $0.082 \mathrm{a}$ & $0.315 \mathrm{ab}$ & $1.519 \mathrm{a}$ & $0.068 \mathrm{a}$ & $0.111 \mathrm{a}$ \\
$\mathrm{T}_{3}$ & $0.737 \mathrm{a}$ & $0.540 \mathrm{a}$ & $0.145 \mathrm{a}$ & $0.084 \mathrm{a}$ & $0.315 \mathrm{a}$ & $1.535 \mathrm{a}$ & $0.070 \mathrm{a}$ & $0.114 \mathrm{a}$ \\
$\mathrm{T}_{4}$ & $0.700 \mathrm{~b}$ & $0.443 \mathrm{c}$ & $0.125 \mathrm{bc}$ & $0.073 \mathrm{~b}$ & $0.301 \mathrm{~b}$ & $1.420 \mathrm{~b}$ & $0.059 \mathrm{~b}$ & $0.105 \mathrm{~b}$ \\
$\mathrm{~T}_{5}$ & $0.657 \mathrm{c}$ & $0.413 \mathrm{~d}$ & $0.119 \mathrm{c}$ & $0.071 \mathrm{~b}$ & $0.273 \mathrm{c}$ & $1.324 \mathrm{c}$ & $0.057 \mathrm{~b}$ & $0.103 \mathrm{~b}$ \\
$\mathrm{LSD}_{0.05}$ & 0.019 & 0.026 & 0.014 & 0.007 & 0.013 & 0.041 & 0.007 & 0.005 \\
$\mathrm{SE}( \pm)$ & 0.063 & 0.008 & 0.004 & 0.002 & 0.004 & 0.013 & 0.002 & 0.001 \\
Level of & 0.0424 & 0.0933 & 0.0049 & 0.0014 & 0.0101 & 0.3033 & 0.0013 & 0.0010 \\
significance & $* *$ & $* *$ & $* *$ & $* *$ & $* *$ & $* *$ & $* *$ & $* *$ \\
$\mathrm{CV}(\%)$ & 1.79 & 3.65 & 6.51 & 5.18 & 2.74 & 1.83 & 7.29 & 2.19 \\
\hline
\end{tabular}

** = Significant at $1 \%$ level of probability, $\mathrm{LSD}=$ Least Significant Difference, $\mathrm{SE}( \pm)=$ Standard Error of means, CV $(\%)=$ Co-efficient of Variation

\section{Nitrogen content}

The highest $\mathrm{N}$ content of $0.737 \%$ was observed in $\mathrm{T}_{3}$ : CNM and the lowest $\mathrm{N}$ content of $0.657 \%$ noted in $\mathrm{T}_{5}$ : Control (Table 2). Application of cowdung with chemical fertilizers increased the $\mathrm{N}$ content in rice grain markedly in $\mathrm{T}_{3}$ : CNM. In the straw of BRRI dhan48, the $\mathrm{N}$ content varied significantly due to different treatments (Table 4). The $\mathrm{N}$ content in the straw ranged from $0.413 \%$ in $\mathrm{T}_{1}$ to $0.54 \%$ in $\mathrm{T}_{3}$. Akhter, $\mathrm{S}$. (2011), Parvez et al. (2008) and Chandel et al. (2003) reported that application of nitrogen from manures and fertilizers increased the $\mathrm{N}$ content both in grain and straw of rice.

\section{Phosphorus content}

Results in Table 1 indicated that phosphorus content in the grain of BRRI dhan 48 varied significantly due to different treatments. Phosphorus content in grain ranged from 0.119 to $0.145 \%$. The highest P content $(0.145 \%)$ in grain was found in $\mathrm{T}_{3}$ : $\mathrm{CNM}$ and the lowest value $(0.119 \%)$ noted in $\mathrm{T}_{5}$ : Control. Phosphorus content in rice straw was influenced significantly due to use of cowdung and fertilizers as shown in Table 3. Khan et al. (2007) observed that the combined application of NPK and organic manures (GM or FYM) significantly increased the paddy and straw yields of rice crop. The highest $\mathrm{P}$ content in straw $(0.084 \%)$ was observed in $\mathrm{T}_{3}$ : CNM and the lowest value $(0.071 \%)$ recorded in $\mathrm{T}_{5}$ : Control. 


\section{Potassium content}

The potassium content both in grain and straw of BRRI dhan 48 varied significantly due to application of cowdung and fertilizers. The $\mathrm{K}$ content ranged from 0.273 to $0.315 \%$ in rice grain and 1.324 to $1.535 \%$ in straw (Table 2). The highest $\mathrm{K}$ content in rice grain $(0.315 \%)$ and straw $(1.535 \%)$ was recorded in $\mathrm{T}_{3}$ : CNM. This is supported by Saleque et al. (1998). The lowest K content in grain ( $0.273 \%)$ and straw (1.324\%) was observed in $\mathrm{T}_{5}$ : Control.

\section{Sulphur content}

The sulphur content both in grain and straw of BRRI dhan 48 was influenced significantly by the combined use of cowdung and fertilizers (Table 2). The highest $\mathrm{S}$ content of $0.07 \%$ in grain was obtained in $\mathrm{T}_{3}$ : $\mathrm{CNM}$ and the lowest value of $0.057 \%$ noted in $\mathrm{T}_{5}$ : Control. All the treatments caused an increasing effect on the $\mathrm{S}$ content of rice grain and the effect of CNM was better compared to fertilizer doses. In case of straw, $\mathrm{S}$ content ranging was from 0.103 to $0.114 \%$. The highest $\mathrm{S}$ content in straw $(0.114 \%)$ was recorded in $\mathrm{T}_{3}$ : CNM and the lowest $\mathrm{S}$ content in straw $(0.103 \%)$ observed in $\mathrm{T}_{5}$ : Control and supported by Chandel et al. (2003).

\subsection{Nutrient Uptake by Grain and Straw of BRRI Dhan 48}

The results of N, P, K and S uptake of BRRI dhan 48 have been presented and discussed below:

Table 3. Effect of combined nutrient management on $\mathrm{N}$ and $\mathrm{P}$ uptake by BRRI dhan 48

\begin{tabular}{ccccccc}
\hline \multirow{2}{*}{ Treatment } & \multicolumn{3}{c}{ N uptake $(\mathbf{k g})$} & \multicolumn{3}{c}{ P uptake (kg) } \\
\cline { 2 - 7 } T1 & Grain & Straw & Total & Grain & Straw & Total \\
T2 & $28.05 \mathrm{~b}$ & $2.560 \mathrm{c}$ & $52.63 \mathrm{c}$ & $5.27 \mathrm{bc}$ & $4.07 \mathrm{~b}$ & $9.34 \mathrm{c}$ \\
T3 & $28.62 \mathrm{~b}$ & $2.790 \mathrm{~b}$ & $58.43 \mathrm{~b}$ & $5.78 \mathrm{~b}$ & $5.21 \mathrm{a}$ & $10.99 \mathrm{~b}$ \\
T4 & $35.55 \mathrm{a}$ & $3.380 \mathrm{a}$ & $70.47 \mathrm{a}$ & $6.99 \mathrm{a}$ & $5.43 \mathrm{a}$ & $12.43 \mathrm{a}$ \\
T5 & $25.62 \mathrm{c}$ & $2.160 \mathrm{~d}$ & $48.53 \mathrm{~d}$ & $4.57 \mathrm{c}$ & $3.78 \mathrm{~b}$ & $8.35 \mathrm{~d}$ \\
LSD0.05 & $20.08 \mathrm{~d}$ & $1.74 \mathrm{e}$ & $35.58 \mathrm{e}$ & $3.64 \mathrm{~d}$ & $2.67 \mathrm{c}$ & $6.31 \mathrm{e}$ \\
SE $( \pm)$ & 1.54 & 0.223 & 3.31 & 0.748 & 0.592 & 0.742 \\
Level of & 0.500 & 0.072 & 1.08 & 0.242 & 0.192 & 0.240 \\
significance & $124.91 * *$ & $214.670 * *$ & $657.82 * *$ & $6.363 * *$ & $5.062 * *$ & $22.344 * *$ \\
CV (\%) & 3.63 & 4.98 & 4.05 & 9.25 & 9.09 & 5.08 \\
\hline
\end{tabular}

** $=$ Significant at $1 \%$ level of probability, $\mathrm{LSD}=$ Least Significant Difference, $\mathrm{SE}( \pm)=$ Standard Error of means, $\mathrm{CV}(\%)=$ Co-efficient of Variation

\section{Nitrogen uptake}

Results indicate that, the $\mathrm{N}$ uptake both by grain and straw of BRRI dhan 48 varied significantly due to application of manure and fertilizers (Table 3). The $\mathrm{N}$ uptake by grain ranging was from 20.08 to $35.55 \mathrm{~kg} \mathrm{ha}^{-1}$ and straw from 1.74 to $3.38 \mathrm{~kg} \mathrm{ha}^{-1}$. The highest $\mathrm{N}$ uptake by grain and straw was recorded 35.55 and $3.38 \mathrm{~kg} \mathrm{ha}^{-1}$ in $\mathrm{T}_{3}$ : CNM, respectively. Duhan and Singh (2002) reported that the rice yield and uptake of nutrients increased significantly with increasing $\mathrm{N}$ levels. The lowest $\mathrm{N}$ uptake by grain $\left(20.08 \mathrm{~kg} \mathrm{ha}^{-1}\right)$ and by straw $\left(1.74 \mathrm{~kg} \mathrm{ha}^{-1}\right)$ found in $\mathrm{T}_{5}$ : Control. The highest total $\mathrm{N}$ uptake $\left(70.47 \mathrm{~kg} \mathrm{ha}^{-1}\right)$ was observed in $\mathrm{T}_{3}$ : INM and the lowest value $\left(35.58 \mathrm{~kg} \mathrm{ha}^{-1}\right)$ found in $\mathrm{T}_{5}$ : Control. This result is an agreement with the findings of Nakashgir et al. (2000).

\section{Phosphorus uptake}

The results presented shows that, the $\mathrm{P}$ uptake both by grain and straw of BRRI dhan 48 was influenced significantly by the application of cowdung and fertilizers (Table 3 ). The $\mathrm{P}$ uptake by grain ranging was from 3.64 to $6.99 \mathrm{~kg} \mathrm{ha}^{-1}$ and that by straw 2.67 to $5.43 \mathrm{~kg} \mathrm{ha}^{-1}$. The maximum $\mathrm{P}$ uptake by grain $\left(6.99 \mathrm{~kg} \mathrm{ha}^{-1}\right)$ and straw $\left(5.43 \mathrm{~kg} \mathrm{ha}^{-1}\right)$ was found in $\mathrm{T}_{3}$ : CNM. The minimum $\mathrm{P}$ uptake by grain $\left(3.64 \mathrm{~kg} \mathrm{ha}^{-1}\right)$ and straw $\left(2.67 \mathrm{~kg} \mathrm{ha}^{-1}\right)$ was found in $\mathrm{T}_{5}$ : Control. Combined use of cowdung and chemical fertilizers is better than only use of chemical fertilizers. The application of cowdung and fertilizers showed significant effect on the uptake of total P by BRRI dhan48 (Table 2). The highest total P uptake (12.43 $\mathrm{kg} \mathrm{ha}^{-1}$ ) was obtained in T3: CNM and the lowest total P uptake (6.307 kg ha-1 $)$ observed in $\mathrm{T}_{5}$ : Control and supported by Akhter, S. (2011). 
Table 4. Uptake of $\mathrm{K}$ and $\mathrm{S}$ by BRRI dhan48 as influenced by the application of combined nutrient management

\begin{tabular}{ccccccc}
\hline \multirow{2}{*}{ Treatment } & \multicolumn{3}{c}{ K uptake (kg) } & \multicolumn{3}{c}{ S uptake (kg) } \\
\cline { 2 - 7 } T1 & Grain & Straw & Total & Grain & Straw & Total \\
T2 & $11.00 \mathrm{c}$ & $79.30 \mathrm{c}$ & $90.50 \mathrm{c}$ & $2.56 \mathrm{c}$ & $6.30 \mathrm{~b}$ & $8.86 \mathrm{c}$ \\
T3 & $12.92 \mathrm{~b}$ & $96.54 \mathrm{~b}$ & $109.50 \mathrm{~b}$ & $2.79 \mathrm{~b}$ & $7.05 \mathrm{a}$ & $9.84 \mathrm{~b}$ \\
T4 & $15.20 \mathrm{a}$ & $99.25 \mathrm{a}$ & $114.4 \mathrm{a}$ & $3.38 \mathrm{a}$ & $7.37 \mathrm{a}$ & $10.75 \mathrm{a}$ \\
T5 & $11.02 \mathrm{c}$ & $73.44 \mathrm{~d}$ & $84.46 \mathrm{~d}$ & $2.16 \mathrm{~d}$ & $5.43 \mathrm{c}$ & $7.59 \mathrm{~d}$ \\
LSD0.05 & $8.35 \mathrm{~d}$ & $49.70 \mathrm{e}$ & $58.05 \mathrm{e}$ & $1.74 \mathrm{e}$ & $3.87 \mathrm{~d}$ & $5.61 \mathrm{e}$ \\
SE $( \pm)$ & 0.999 & 2.69 & 3.20 & 2.23 & 0.367 & 0.424 \\
Level of & 0.324 & 0.874 & 1.04 & 0.072 & 0.119 & 0.137 \\
significance & $25.913^{* *}$ & $1605.12^{* *}$ & $2018.72^{* *}$ & $1.552^{* *}$ & $7.931^{* *}$ & $16.163^{* *}$ \\
CV (\%) & 5.55 & 2.20 & 2.28 & 5.74 & 3.96 & 3.24
\end{tabular}

** $=$ Significant at $1 \%$ level of probability, $\mathrm{LSD}=$ Least Significant Difference, SE $( \pm)=$ Standard Error of means, $\mathrm{CV}(\%)=$ Co-efficient of Variation

\section{Potassium uptake}

The results indicate that the $\mathrm{K}$ uptake by grain and straw of BRRI dhan48 varied significantly by different treatments (Table 4). The $\mathrm{K}$ uptake by grain increase from 8.35 in $\mathrm{T}_{5}$ : Control to $15.20 \mathrm{~kg} \mathrm{ha}^{-1}$ in $\mathrm{T}_{3}$ : CNM. The $\mathrm{K}$ uptake by straw ranging was from 49.70 in $\mathrm{T}_{5}$ : Control to $99.25 \mathrm{~kg} \mathrm{ha}^{-1}$ in $\mathrm{T}_{3}$ : CNM, respectively. The total $\mathrm{K}$ uptake by grain and straw was also affected significantly by different treatments. The highest total K uptake (114.4) was obtained in $\mathrm{T}_{3}$ : CNM and the lowest value (58.05) in $\mathrm{T}_{5}$ : Control. This result is strongly supported by Nakashgir et al. (2000). The results are also in agreement with Meena et al. (2003)

\section{Sulphur uptake}

Sulphur uptake by grain and straw was influenced significantly due to application of different treatments (Table 4). The $\mathrm{S}$ uptake by grain and straw ranging was from 1.74 to 3.38 and 3.87 to $7.37 \mathrm{~kg}$ ha-1, respectively. The highest $\mathrm{S}$ uptake by grain (3.38 kg ha-1) and straw (7.37 kg ha-1) was found in T3: CNM. The lowest S uptake by grain (1.74) and straw (3.87) was found in T5 (control). The total $\mathrm{S}$ uptake by grain and straw was also influenced significantly by different treatments (Table 4). The highest total S uptake (10.75) was found in T3: CNM and the lowest value (5.61) in T5: Control. This result is similar to Sarfaraz et al. (2002).

\section{Conclusion}

It can be concluded that combined use of manure and fertilizers significantly increased nutrient content and uptake by BRRI dhan 48 . The treatment $\mathrm{T}_{3}$ : CNM revealed the highest NPKS uptake while the lowest value was recorded over the control. Integrated Nutrient Management practice keeps soil healthy with higher yield of BRRI dhan48. So, farmer's should follow this technique to minimize soil pollution and get economically benefitted for rice cultivation. Further research should be recommended for more confirmation of the result.

\section{Acknowledgement}

Authors gave gratitude towards the Ministry of Science and Technology of Bangladesh for providing financial support to conduct the research work.

\section{Conflict of Interest}

The authors have no conflict of interest to report.

\section{Authors' Contributions}

Nahid Kaisar conducted the experiment and analyzed the data. Abu Zofar Md. Moslehuddin and Mahbubul Alam Tarafder provided help for the experimental design and supervised in the whole experiment. Md. Sohanur Rahman contributed in data presentation, analysing data, searching journal for publication and finally manuscript processing and writing of this article. This article was read and approved by all authors for final Publication.

\section{References}

Akhter, S. (2011). Effects of nitrogen supplied from manures and fertilizers on the growth and yield of BRRI Dhan29. MS Thesis, Department of Soil Science, Bangladesh Agricultural University, Mymensingh. Pages?

Arif, M., Tasneem, M., Fiaz, B., Yaseen, G., \& Iqbal, R. M. (2014). Effect of combined use of organic manures 
and inorganic fertilizers on yield and yield components of rice. Journal of Research, 52(2), 197-206

Bair, W. (1990). Characterization of environment of sustainable agriculture in Semi Arid Tropics. In: Proc. Sustainable agriculture. Issues, Perspectives and prospects Semi Arid Tropics (Ed. Singh, R.P.) Hydrabad, India. Indian Society Agronomy, 1, pp: 90-124. https://doi.org/10.19103/as.2017.0023.33

Chandel, R. S., Singh, K., Singh, A. K., \& Sudhakar, P. C. (2003). Effect of sulphur nutrition in rice (Oriza sativa L.) and mustard (Brassica juncea L. Czern and Coss) grown in sequence. Indian Physiol, 8, 155-159.

DAE. (Department of Agriculture Extension (2019). Agriculture in Bangladesh at a glance. Panya Nirdeshika, Khamarbari, Farmgate, Dhaka.pages?

Duhan, B. S., \& Singh, M. (2002). Effect of green manuring and nitrogen on the yield and uptake of micronutrients by rice. Journal Indian Society of Soil Science, 50, 78-180.

Karim, Z., Miah, M.M.V., \& Razia, S. (1994). Fertilizer in the national economy and sustainable environment. Asia Pacific Environment Development, 2, 48-67.

Khan, M. U., Qasim, M., \& Khan, I. U. (2007). Effect of combined nutrient management on crop yields in ricewheat cropping system. Sarhad Journal of Agriculture, 23, 1019-1025.

Malika. (2011). Combined use of manures and fertilizers for maximizing the growth and yield of BINA dhan7. MS thesis, Department of Soil Science, Bangladesh Agricultural University, Mymensingh.pages

Meena, S. L., Singh, S., \& Shivay, Y. S. (2003). Response of rice (Oryza sativa) to N and K application in sandy clay loam soils. Indian Journal Agricultural Science, 73, 443-447.

Nakashgir, G. H., Handoo, G. M., \& Wani, S. A. (2000). Transformation availability and relative response of rice to applied $\mathrm{K}$ in presence of ammonical- nitrogen in Alfisols of Kashmir. Journal of Potassium Research, 16, $55-58$.

Nambiar, K. K. M. (1991). Long term fertility effects on wheat productivity. Wheat for the non-traditional warm areas: A proceeding of the International Conference in Mexico DF (Mexico) CYMMYT., pp. 516-521.

Parvez, M. S., Islam, M. R., Begum, M. S., Rahman, M. S., \& Abedin Miah, M. J. (2008). Combined use of manure and fertilizers for maximizing the yield of BRRI dhan 30. Journal of Bangladesh Society of Agricultural Science Technology, 5, 257-260.

Qian, H., Xiu, M. L., Rong, G. L., Zhang, L., Ren, Y. L., Lan, Y. H., Hua, J., Hong, S. C., \& Quan, W. F. (2011). Effect of long-term located organic-inorganic fertilizer application on rice yield and soil fertility in red soil area of China. Scientia Agricultura Sinica, 44, 516-523.

Rahman, M. S., Islam, M. R., Rahman, M. M., \& Hossain, M. I. (2009). Effect of cowdung, poultry manure, and urea on the yield and nutrient uptake of BRRI dhan29. Bangladesh Research Publication Journal, 2(2), 552558.

Rijpma, J., \& Jahiruddin, M. (2004). National strategy and plan for use of soil nutrient balance in Bangladesh. Final Report of short term assignment, SFFP- DANIDA.

Saleque, M. A., Saha, P. K., Panullah, G. M., \& Bhuiyan, N. I. (1998). Response of wetland rice to potassium in farmers field of the Barind tract. Bangladesh Journal of Plant Nutrition, 21, 39-47. https://doi.org/10.1080/01904169809365381

Sarfaraz, M., Mehdi, S. M., Sadiq, M., \& Hassan, G. (2002). Effect of sulphur on yield and chemical composition of rice. Sarhad journal of Agriculture, 18, 411-414.

\section{Copyrights}

Copyright for this article is retained by the author(s), with first publication rights granted to the journal.

This is an open-access article distributed under the terms and conditions of the Creative Commons Attribution license (http://creativecommons.org/licenses/by/4.0/). 